\title{
DIFFERENT CLINICAL PRESENTATIONS OF RECURRENT EPISODE OF MAJOR DEPRESSIVE DISORDER WITH OR WITHOUT POSTTRAUMATIC STRESS DISORDER
}

\author{
Maja Simonović1,2, Tatjana Milenkovićn ${ }^{1}$ Ninoslava Simić ${ }^{1,2}$, Bojan Nedović ${ }^{1}$
}

\begin{abstract}
The aim of this study was comparison of the severity of the recurrent episode in the group of subjects suffering from Major Depressive Disorder with comorbid Posttraumatic Stress Disorder and the group of subjects suffering only from Major Depressive Disorder. A total of 120 subjects were assessed and divided into two groups. Group D/PTSD consisted of subjects who fulfilled diagnostic criteria for recurrent episode of Major Depressive Disorder and comorbid Posttraumatic Stress Disorder. Group D/only consisted of subjects who fulfilled diagnostic criteria for Recurrent episode of Major Depressive Disorder. Assessments were performed using the following instruments: Montgomery-Asberg Depression Rating Scale, Hamilton Depression Rating Scale and Quick Inventory for Depressive Symptomatology Self -Report Version. Statistical analyses were performed using chi square and independent-samples t-test. Results suggest that recurrent episode of Major Depressive Disorder occurring in comorbidity with Posttraumatic stress disorder is more severe than the recurrent episode in the category of patients suffering from recurrent episode of Major Depressive Disorder only and that recurrent episode occurring in comorbidity with Posttraumatic stress disorder might represent a significant clinical entity.
\end{abstract}

Acta Medica Medianae 2019;58(3):67-71.

Key words: stress disorders; post-traumatic; depressive disorder, major

${ }^{1}$ University of Niš, Faculty of Medicine, Serbia

${ }^{2}$ Clinic for Mental Health, Clinical Center, Niš, Serbia

Contact: Maja Simonović

Blvd dr Zoran Djindjić 81, 18000 Niš, Serbia

E-mail: simonovicmaja@gmail.com, maja.simonovic@medfak.ni.ac.rs

\section{Introduction}

A large number of individuals are exposed to traumatic events: death, the threat of death, or serious injury to the person and others. Previously without manifested psychopathology, a number of individuals develop symptoms. The manifested group of symptoms corresponds, most often, to the diagnosis of posttraumatic stress disorder (PTSD), but also Major depressive disorder (MDD), and these two disorders were often present in comorbidity (1).

MDD is a well-known clinical entity with clearly defined therapeutic guidelines. However, in the comorbidity with PTSD, MDD becomes a confusing entity. Symptoms of MDD are clearly present, but do not respond to treatment with antidepressants and psychotherapeutic interventions, do not have the usual episodic flow and are accompanied by a significant decrease in functioning and suicidality $(2,3)$. Comorbid altered patterns of cognitive, affective, and vegetative responses related to PTSD make the clinical presentation of patients difficult and disturbing $(4,5)$. Faced with such a complex presentation, the clinician has a dilemma whether the diagnosis of MDD is reliable. Literature data show that variations in causal factors of MDD are associated with variations in the clinical picture, that individuals with comorbidity of MDD and PTSD have different neurobiological profiles than those with PTSD only (6-8).

\section{The Aim}

This study was designed to compare clinical presentations of recurrent episode of MDD, with and without posttraumatic stress disorder by using the self-rating and clinician-rated instruments for measuring depression severity. 


\section{Materials and methods}

\section{Study design}

This cross-sectional study was performed at The Clinic for Mental Health, Clinical Center Niš, Serbia. The subjects, treatment-seeking, were initially diagnosed as suffering from recurrent episode of the Major Depressive Disorder (MDD) with or without PTSD, using The Structured Clinical Interview for DSM-IV Axis I Disorders (SCID-I, modified) (9). The study was performed according to Declaration of Helsinki and all procedures were approved by the Institutional Review Boards at Clinical Center Niš.

\section{Participants}

A total of 120 , consecutively admitted subjects, all males, aged between 25 and 65, were included in the analysis. The subjects were included in the study if they met diagnostic criteria for recurrent episode of MDD with or without PTSD, according to Diagnostic and Statistical Manual of Mental Disorders - DSM-IV (9). The exclusion criteria were: lifetime history of psychotic disorder, severe somatic illness, alcohol dependence disorder, and epilepsy. The subjects were divided into two groups: Group D/PTSD consisted of the subjects suffering from recurrent Episode of MDD and PTSD. Group D/only consisted of the subjects suffering from a recurrent episode of MDD only. Each group consisted of 60 subjects. The assessments of the severity of the recurrent episodes were performed within 14 days upon admission.

\section{Procedures}

After having been informed, the participants completed the study procedures. Sociodemographic characteristics were assessed using the semi-structured clinical interview. The severity of the recurrent episode of MDD was assessed using clinician-rated instruments Montgomery-Asberg Depression Rating Scale (MADRS) (10) and Hamilton Depression Rating Scale (HDRS-17) (11). Self-rating was performed using Quick Inventory for Depressive Symptomatology Self -Report Version (QUIDS-SR) (12).

\section{Measures}

Montgomery-Asberg Depression Rating Scale, as a clinician- rated instrument was used to measure the presence and the severity of the MDD. The scale consists of 10 items. Each item yields score 0 to 6 on the Likert scale. The overall score determines the severity of the disorder. The higher numerical rating determines more severe disorder. The items assess somatic, cognitive, vegetative and anxious symptoms. MADRS score higher or equal to 20 is considered significant in diagnosing single episode of MDD (10).
Hamilton Depression Rating Scale, as a clinician-rated instrument was used to measure the presence and the severity of depressive symptoms. The scale consists of 17 items. Each item is scored from 0 to 2 or from 0 to 4 on the Likert scale; total scores can range from 0 to 52 . The higher numerical rating determines more severe disorder. The scale predominantly assesses cognitive and vegetative symptoms, with relatively few items related to anxiety, social, motor, and mood factors (11).

Quick Inventory for Depressive Symptomatology Self-Report Version is a self-rating instrument designed for screening of depressive symptoms. It consists of 16 questions that include all Diagnostic and Statistical Manual for Mental Disorders-Fourth Edition (DSM-IV) criterion items required to diagnose MDD. The QIDS-SR utilizes equivalent weightings for each symptom item as well as clearly stated anchors for each response. The QIDS-SR 16 scoring system converts each of the 16 response items into the nine symptom criteria domains of MDD (i.e. sad mood, concentration, self-criticism, suicidal ideation, interest, energy/fatigue, sleep disturbance, decrease /increase in appetite/weight, and psychomotor agitation/retardation) and provides a total score ranging from 0 to 27 (12).

Statistical significance between groups was defined as a two-sided $p$ value of 0.05 for all analyses, which were carried out using the SPSS software package, v15.0 (13).

\section{Results}

The analysis of demographic data showed that the average age of subjects in the Group D/PTSD was 43.05 years ( $S D=7.15$ ), and in 44.62 years $(\mathrm{SD}=9.79)$ in the Group D/only. The sample was $100 \%$ Caucasian. In D/PTSD group $80 \%$ of subjects were married, $5 \%$ were single, $15 \%$ were divorced. In D/only group $61.67 \%$ of subjects were married, $15 \%$ were single, and $18.33 \%$ were divorced. In D/PTSD group, $11.67 \%$ of subjects completed elementary school, $85 \%$ completed secondary school, and $3.33 \%$ had earned master's degree. In D/only group $25 \%$ of subjects completed elementary school, $60 \%$ completed secondary school, and $15 \%$ had earned master's degree. All were employed at the time of the interview. A chi-square test reported significant difference in the educational structures of the investigated groups $(p=.007)$. There were no significant differences on participant characteristics regarding age and marital status between two groups.

The independentsamples t-tests examined potential group differences on the MDRS and HDRS scores. The D/PTSD group reported higher MDRS and HDRS-17 total scores ( $p<.001$ ) (Table 1$)$. The total scores for D/PTSD group were also higher with respect to QIDS-SR scale $(p<.001)$. (Table 2$)$. 
Table 1. MADRS and HDRS total scores for D/PTSD and D/only group

\begin{tabular}{||c|c|c|c|c|c||c|c|c|c|c||c||}
\cline { 2 - 11 } \multicolumn{1}{c|}{} & \multicolumn{9}{c||}{ D/PTSP } & \multicolumn{6}{c||}{ D/only } & p \\
\cline { 2 - 12 } \multicolumn{1}{c|}{} & $\mathrm{X}$ & SD & CV & $95 \%$ & CI & X & SD & CV & $95 \%$ & CI & \\
\hline \hline MADRS_sum & 33.17 & 6.47 & 19.50 & 31.50 & 34.84 & 23.40 & 4.23 & 18.07 & 22.31 & 24.49 & ${ }^{* * *} .000$ \\
\hline HDRS_sum & 28.48 & 5.75 & 20.18 & 27.00 & 29.97 & 22.87 & 4.86 & 21.23 & 21.61 & 24.12 & ${ }^{* * *} .000$ \\
\hline
\end{tabular}

Table 2. The values of the total scores of QIDS instrument

\begin{tabular}{|c|c|c|c|c|c|c|c|c|c|c|c|}
\hline & \multicolumn{5}{|c|}{ D/PTSD } & \multicolumn{5}{|c|}{ D/only } & \multirow{2}{*}{$\mathrm{p}$} \\
\hline & $x$ & SD & $\mathrm{Cv}$ & $95 \%$ & CI & $x$ & SD & $\mathrm{Cv}$ & $95 \%$ & $\mathrm{CI}$ & \\
\hline QQIDS_sum & 18.38 & 4.52 & 0.58 & 17.22 & 19.55 & 15.68 & 3.94 & 0.51 & 14.66 & 16.70 & ${ }^{* * * *} .000$ \\
\hline
\end{tabular}

\section{Discussion}

This study compared the clinical presentation of individuals with recurrent episode of Major depressive disorder, with and without PTSD. D/PTSD group was rated as having more severe depression measured by the MADRS, HDRS-17 and QIDS-SR total score.

Comparison of the severity of the recurrent episode of MDD, measured by MADRS, HDRS-17 and QIDS-SR, showed that the severity of the recurrent episode was higher in the group of subjects with PTSD than in the group of subjects suffering from MDD only as demonstrated in other studies (14). Also, from the clinical perspective, results suggest that the recurrent episode of MDD occurring in comorbidity with PTSD represents a significant clinical entity (15). High values on scales measuring the severity of a recurrent episode of MDD suggest that the clinical diagnosis of MDD in comorbidity with PTSD is adequate $(16,17)$.

The recurrent episode of MDD occurring in comorbidity with PTSD often remains underdiagnosed. The main reason is the overlap of the symptoms of these entities (18). Our approach suggests that the overlap of symptomatology should not be taken as a criterion that excludes, but as a criterion that confirms another diagnosis. The nature of psychopathology is essentially complex and subject to change, and what is now conceptualized as a simultaneous event of multiple disorders can be better reformulated as the complexity of more psychiatric conditions, and as the fact that the increase in complexity is an obvious predictor of more severe disorder, of disability and of use of the health services (8).

Furthermore, the reason for underdiagnoses of the recurrent episode of MDD comorbid to PTSD may be that depressive symptomatology is often overshadowed with the flamboyant symptomatology of posttraumatic stress disorder and therefore remains unrecognized. The nature of intrusive symptomatology implies that the traumatic contents persistently intrude into the consciousness of individ- uals. Intrusive thoughts, features of nightmares, intrusions of morbid images and episodes of reexperiencing of events, increased psychological and physiological reactivity, high tension, irritability, insomnia, cognitive dysfunction, symptoms of avoidance and affective restriction, manifested in detachment, alienation, strangeness and the sense of foreshortened future, all suggest that the dominant complaints of the person seeking treatment relate to the symptoms of posttraumatic stress disorder. The disturbing nature of a real-life traumatic event associated with simultaneous existence of intrusive cognitive contents and high vegetative hyperarousal implies the absence of thinking activity related to the analysis of the experience, of reflecting, perceiving and analyzing thoughts and affects $(19,20)$.

Also, the nature of the altered affective reactivity in the posttraumatic stress disorder is that it interferes with the reporting of depressive symptoms by patients. In posttraumatic stress disorder, deverbalization, dissociation, and resomatization of affects occur (21). Predominant feature is the loss of the signaling function of emotions (22). The emotions lose the capacity to serve as signals and no longer lead to organized and adaptive action, but lead to disorganized patterns of response, to flight or fight reactions. (23).

Finally, limitations of the current study should be addressed. First, we recruited a modest number of participants for this study. Second, due to the nature of the PTSD screening, the severity of PTSD was unable to be determined, hindering examination of how PTSD severity affects MDD severity. With these limitations in mind, the study has several strengths. Specifically, structured clinical interviews (i.e., the MADRS, the HDRS-17, and QIDS-SR) were utilized in the assessment of recurrent episode of MDD. Additionally, all participants in the sample met diagnostic criteria for MDD providing a homogeneous sample for the comparison of a subject with and without PTSD. 


\section{Conclusion}

The obtained results suggest the validity of the diagnostic construct of comorbidity of MDD and PTSD. Our data on the severity of current recurrent episodes of MDD in subjects suffering from PTSD indicate the importance of MDD diagnostics and the necessity of determining different pharmacological and psychotherapeutic treatment approaches.

\section{Competing interests}

The authors declare no competing interests.

\section{References}

1. Sherin JE, Nemeroff CB. Post-traumatic stress disorder: The neurobiological impact of psychological trauma. Dialogues in Clinical Neuroscience 2011; 13:263-78. [PubMed]

2. Stander VA, Thomsen CJ, Highfill-McRoy RM. Etiology of depression comorbidity in combat-related PTSD: A review of the literature. Clinical Psychology Review 2014; 34(2):87-98. [PubMed] [CrossRef]

3. Flory JD, Yehuda R. Comorbidity between posttraumatic stress disorder and major depressive disorder: alternative explanations and treatment considerations. Dialogues in Clinical Neuroscience 2015; 17(2):141-50. [PubMed]

4. Ramsawha HJ, Fullerton CS, Herberman HB, Kessler C, Ursano RJ. Risk for suicidal behaviors associated with PTSD, depression, and their comorbidity in the U.S. Army, Journal of Affective Disorders 2014; 161:116-22. [PubMed] [CrossRef]

5. Kimbrel NA, Meyer EC, DeBeer BB, Gulliver SB, Morissette SB. A 12-Month Prospective Study of the Effects of PTSD-Depression Comorbidity on Suicidal Behavior in Iraq/Afghanistan-Era Veterans. Psychiatry research 2016; 243:97-9. [PubMed] [CrossRef]

6. Yehuda R, Henn-Haased C, Lehnerrab A, Daskalakisab $P$, Marmard CR, Michael J et al. Lower Methylation of Glucocorticoid Receptor Gene Promoter 1F in Peripheral Blood of Veterans with Posttraumatic Stress Disorder. Biological Psychiatry 2015; 77(4):356-64. [PubMed] [CrossRef]

7. Smoller JW. The Genetics of Stress-Related Disorders: PTSD, Depression, and Anxiety Disorders. Neuropsychopharmacology 2016; 41(1):297-319. [PubMed] [CrossRef]

8. Shin LM, Bush G, Whalen PJ, Handwerger K, Cannistraro PA, Wright CI, et al. Dorsal anterior cingulated function in posttraumatic stress disorder. Journal of Traumatic Stress 2007; 20(5):701-12. [PubMed] [CrossRef]

9. American Psychiatric Association (US). Diagnostic and statistical manual of mental disorders. 4th ed. Washington; 1994.

10. Montgomery SA, Asberg M. A new depression scale designated to be sensitive to change. $\mathrm{Br}$ J Psychiatry 1979; 134:382-9. [PubMed] [CrossRef]
11. Hamilton M. A rating scale for depression. J Neurol Neurosurg Psychiatry 1969; 23:56-62. [PubMed] [CrossRef]

12. Rush AJ, Trivedi MH, Ibrahim HM, Carmody TJ, Arnow B, Klein DN, et al. The 16-item Quick Inventory of Depressive Symptomatology (QIDS) Clinician Rating (QIDS-C) and Self-Report (QIDS-SR): A psychometric evaluation in patients with chronic major depression. Biological Psychiatry 2003; 54:573-83. [PubMed] [CrossRef]

13. Levesque R. SPSS Programming and Data Management: A Guide for SPSS and SAS Users. $4^{\text {th }}$ ed. Chicago (IL): SPSS Inc; 2007.

14. O'Donnell ML, Creamer M, Pattison P. Posttraumatic Stress Disorder and Depression Following Trauma: Understanding Comorbidity. Am J Psychiatry 2004; 161(8):1390-6. [PubMed] [CrossRef]

15. Marmar CR, Schlenger W, Henn-Haase C, Qian M, Shalev A, Kulka RA et al. Course of Posttraumatic Stress Disorder 40 Years After the Vietnam War. Findings from the National Vietnam Veterans Longitudinal Study. JAMA Psychiatry 2015; 72(9):875-81. [PubMed] [CrossRef]

16. Gaudiano BA, Zimmerman M. Does comorbid posttraumatic stress disorder affect the severity and course of psychotic major depressive disorder? J Clin Psychiatry 2010; 71(4):442-50. [PubMed] [CrossRef]

17. Campbell DG, Felker B, Liu CF, Yano EM, Kirchner JAE, Chan D, et al. Prevalence of Depression PTSD Comorbidity: Implications for Clinical Practice Guidelines and Primary Care-based Interventions. J Gen Intern Med. 2007; 22(6):711-8. [PubMed] [CrossRef]

18. Afzali $M$, Sunderland $M$, Teessona $M$, Carragher $N$, Mills $K$, Slade T. A network approach to the comorbidity between posttraumatic stress disorder and major depressive disorder: The role of overlapping symptoms. Journal of Affective Disorders 2017; 208 (1): 490-6. [PubMed] [CrossRef]

19. Naegeli C, Zeffiro, Piccirelli M, Jaillard J, Weilenmanna A, Hassanpour $K$ et al. Locus Coeruleus Activity Mediates Hyperresponsiveness in Posttraumatic Stress Disorder. Biological Psychiatry 2018; 83(3):254-62. [PubMed] [CrossRef]

20. Krystal JH, Abdallah CG, Pietrzak RH, Averill LA, Harpaz-Rotem I, Levy I et al. Locus Coeruleus Hyper- 
activity in Posttraumatic Stress Disorder: Answers and Questions. Biological Psychiatry 2018; 83(3):197-9. [PubMed] [CrossRef]

21. Brewin CR. The nature and significance of memory disturbance in posttraumatic stress disorder. Annual Review of Clinical Psychology 2011; 7:203-27. [PubMed] [CrossRef]
22. Freud S. Inhibitions, symptoms and anxiety. In Standard Edition, Vol 20. London: Hogarth Press; 1975.

23. Hyer L, Stanger $E$, Boudewyns P. The interaction of posttraumatic stress disorder and depression among older combat veterans. J Clin Psychology1999; 55 (9): 1073-83. [PubMed] [CrossRef]

\title{
KLINIČKA PREZENTACIJA REKURENTNE EPIZODE VELIKOG DEPRESIVNOG POREMEĆAJA SA POSTTRAUMATSKIM STRESNIM POREMEĆAJEM ILI BEZ NJEGA
}

\author{
Maja Simonović1,2, Tatjana Milenkovićn ${ }^{1}$ Ninoslava Simić ${ }^{1,2}$, Bojan Nedović ${ }^{1}$
}

\author{
${ }^{1}$ Univerzitet u Nišu, Medicinski fakultet, Niš, Srbija \\ ${ }^{2}$ Klinika za mentalno zdravlje, Klinički centar Niš, Niš, Srbija \\ Kontakt: Maja Simonović \\ Bulevar dr Zorana Đinđića 81, 18000 Niš, Srbija \\ E-mail: simonovicmaja@gmail.com, \\ maja.simonovic@medfak.ni.ac.rs
}

Cilj rada je upoređivanje težine aktuelne rekurentne epizode u grupi subjekata koji pate od velikog depresivnog poremećaja i komorbidnog posttraumatskog stresnog poremećaja sa grupom subjekata koji pate samo od velikog depresivnog poremećaja. Ukupno 120 subjekata sagledano je i raspoređeno u dve grupe. U grupu D/PTSP raspoređeni su subjekti koji su ispunjavali dijagnostičke kriterijume za rekurentnu epizodu velikog depresivnog poremećaja i posttraumatski stresni poremećaj. U grupu D/only raspoređeni su subjekti koji su ispunjavali dijagnostičke kriterijume za rekurentnu epizodu velikog depresivnog poremećaja. Procena težine rekurentne epizode vršena je korišćenjem instrumenata: Montgomery-Asberg skale za depresiju, Hamiltonove skale za depresiju i inventara depresivne simptomatologije. Podaci su analizirani Studentovim t-testom nezavisnih uzoraka. Rezultati su pokazali da je težina aktuelne rekurentne epizode velikog depresivnog poremećaja bila veća kod subjekata koji su patili od komorbidnog posttraumatskog stresnog poremećaja u odnosu na subjekte koji su patili samo od rekurentne epizode velikog depresivnog poremećaja i potvrđuju da predstavlja značajan klinički entitet.

Acta Medica Medianae 2019;58(3):67-71. poremećaj

Ključne reči: stresni poremećaj, posttraumatski poremećaj, veliki depresivni 